\title{
Factors affecting the viability of Staphylococcus aureus and production of enterotoxin during processing and storage of white-brined cheese
}

\author{
Anas A. Al-Nabulsi, ${ }^{1 *}$ ๑ Tareq M. Osaili, ${ }^{1,2}$ Roa A. AbuNaser, ${ }^{1} \odot$ Amin N. Olaimat, ${ }^{3}$ Mutamed Ayyash, ${ }^{4 *}$ (1) \\ Murad A. Al-Holy, ${ }^{3}$ (D) Khaled M. Kadora, ${ }^{5}$ and Richard A. Holley ${ }^{6}$ (D) \\ ${ }^{1}$ Department of Nutrition and Food Technology, Jordan University of Science and Technology, Irbid 22110, Jordan \\ ${ }^{2}$ Department of Clinical Nutrition and Dietetics, University of Sharjah, Sharjah, PO Box 27272, United Arab Emirates \\ ${ }^{3}$ Department of Clinical Nutrition and Dietetics, Faculty of Allied Health Sciences, Hashemite University, Zarqa 13115, Jordan \\ ${ }^{4}$ Department of Food, Nutrition, and Health, College of Food and Agriculture, United Arab Emirates University, Al-Ain 15551, United Arab Emirates \\ ${ }^{5}$ Department of Food Laboratories, Jordan Food and Drug Administration, Amman 11181, Jordan \\ ${ }^{6}$ Department of Food and Human Nutritional Sciences, University of Manitoba, Winnipeg, MB R3T 2N2, Canada
}

\section{ABSTRACT}

Staphylococcus aureus is a major foodborne pathogen that causes severe disease in humans. It is commonly found in milk and dairy products, particularly in fresh brined cheese. Our aim was to investigate the behavior of Staph. aureus and enterotoxin production during the storage of white-brined cheese prepared with or without a starter culture and stored in a 10 or $15 \% \mathrm{NaCl}$ brine at $10^{\circ} \mathrm{C}$ and $25^{\circ} \mathrm{C}$ for $28 \mathrm{~d}$. $\mathrm{NaCl}$ concentration, water activity, $\mathrm{pH}$, and number of Staph. aureus and lactic acid bacteria were determined in cheese and brine. Only 1 of 4 Staph. aureus strains (ATCC 439) was positive for enterotoxin production, and its production was detected in unsalted UHT milk, but not in salted milk or in any of the cheese treatments held at $37^{\circ} \mathrm{C}$ for 1,3 , or 7 d. Staphylococcus aureus grew in the cheese stored in both brines at $10^{\circ} \mathrm{C}$ and $25^{\circ} \mathrm{C}$, regardless of the presence of a starter culture, although the latter significantly reduced Staph. aureus growth in cheese or its brine at $10^{\circ} \mathrm{C}$. Staphylococcus aureus numbers were increased by 2.26 and $0.47 \log _{10} \mathrm{cfu} / \mathrm{g}$ in cheese stored in 10 and $15 \% \mathrm{NaCl}$ brine, respectively, in the presence of starter culture, and by 2.78 and $2.96 \log _{10} \mathrm{cfu} / \mathrm{g}$, respectively, in the absence of starter culture at $10^{\circ} \mathrm{C}$. Nonetheless, the pathogen grew, but at a lower number in the brines. The salt concentration of cheese stored in $10 \%$ brine remained at approximately $5 \%$ during storage; however, in $15 \%$ brine, the salt concentration increased to almost $8 \%$ (wt/wt) by $28 \mathrm{~d}$. The addition of a starter culture, high salt concentration, low tem-

Received January 5, 2020

Accepted April 1, 2020.

*Corresponding authors: anas_nabulsi@just.edu.jo and mutamed. ayyash@uaeu.ac.ae perature, and $\mathrm{pH}(\sim 5.2)$ had inhibitory effects on the growth of Staph. aureus. Moreover, lactic acid bacterial numbers increased considerably in cheese and brine by $\mathrm{d} 28$. The use of starter cultures, salt (15\%), and low storage temperature $\left(10^{\circ} \mathrm{C}\right)$ reduced the growth of Staph. aureus, and salt may have prevented enterotoxin production in white-brined cheese.

Key words: Staphylococcus aureus, lactic acid bacteria, starter culture, staphylococcal enterotoxin, white-brined cheese

\section{INTRODUCTION}

White-brined cheese is a traditional cheese product in communities from North Africa, the Middle East, and the Gulf Cooperation Council countries (Ayyash et al., 2013). White-brined cheese is traditionally consumed either fresh or after ripening in a brined solution $(5-20 \% \mathrm{NaCl})$ at room temperature (Ayyash and Shah, 2011). White-brined cheese is a perishable food that can act as a medium for the rapid growth of foodborne pathogens. It serves as an ideal microenvironment for the growth of foodborne pathogens, such as Escherichia coli O157:H7, Listeria monocytogenes, and Staphylococcus aureus because of its high water activity, $\left(\mathbf{a}_{\mathbf{w}}\right.$, 0.94-0.96), high protein $(21.1 \%)$, moderate fat content $(10.4 \%)$, relative high $\mathrm{pH}$ value (6.1-5.2), and the absence of competitive starter culture (Al-Holy et al., 2012). The binomial variation in $\mathrm{pH}$ values (acidic and alkaline) has an adverse effect on pathogens' growth. A similar adverse effect is reported when salt concentration is increased. The thermal heat treatments $\left(65^{\circ} \mathrm{C} / 30\right.$ $\min , 72^{\circ} \mathrm{C} / 15 \mathrm{~s}, 135^{\circ} \mathrm{C} / 3 \mathrm{~s}$ ) are designed to inactivate the foodborne pathogens (Cebrián et al., 2016).

Staphylococcal foodborne intoxication is among the common forms of bacterial food poisoning outbreaks (Dayan et al., 2016). This organism can grow in vari- 
ous foods, such as milk, cream, cream-filled pastries, butter, ham, cheeses, sausage, cooked meals, sandwich filling, meat and meat products, poultry and egg products, and salads, such as egg, tuna, chicken, potato, and macaroni (Gatadi et al., 2019). Moreover, any food, such as white-brined cheese, which requires considerable handling during preparation and is kept at warm temperatures or brined in low-salt solution after preparation, is also commonly implicated in staphylococcal food poisoning (Le Loir et al., 2003; Ahmed et al., 2019).

Currently, the World Health Organization has classified Staph. aureus as a high-tier priority II pathogen (WHO, 2017). In 2015, the European Food Safety Authority reported that staphylococcal toxins caused 434 out of the $4,362(9.9 \%)$ foodborne-disease outbreaks. In the 39 strong-evidence outbreaks caused by staphylococcal toxins, cheese was the most commonly implicated food vehicle, followed by mixed food (EFSA, 2018). In a report by the Center for Disease Control and Prevention, 75 outbreaks occurred between 2009 and 2015 because of contamination with Staph. aureus (of those, $40 \%$ were related to Staph. aureus enterotoxins), with 1681 illnesses and 86 incidents of hospitalization (Dewey-Mattia et al., 2018).

Further, Singh and Prakash (2008) indicated that Staph. aureus was isolated from milk products, including curd and cottage cheese. Coton et al. (2010) reported that Staphylococcus strains (227 isolates) were obtained from cheese in France. Recently, Staph. aureus was found in 142 samples of 350 dairy products in Egypt, where positive rates of Staph. aureus detection in cheeses were up to $41 \%$ (Ahmed et al., 2019). For the first time, an oxacillin-susceptible mecA-positive Staph. aureus was detected in cheese samples in Europe (Quijada et al., 2019). The prevalence of Staph. aureus in Brazilian milk and cheese samples was $61 \%$ and $100 \%$, respectively (de Oliveira et al., 2019).

It is evident that Staph. aureus is among the major causes of foodborne illness. In response, Adhikari et al. (2018) have monitored the Staph. aureus in vacuumpacked canned cheeses as influenced by storage time and temperature. Mohammadi and Hanifian (2015) have investigated the growth and enterotoxin production of Staph. aureus in Iranian ultra-filtered white cheese. However, information about the survival of Staph. aureus during the processing and storage of white-brined cheese is not available. Therefore, the objective of the current study was to investigate the behavior of Staph. aureus and enterotoxin production during the processing and storage of white-brined cheese in the presence or absence of a starter culture when stored at different salt concentrations and temperatures.

\section{MATERIALS AND METHODS}

\section{Preparation of Culture}

Four strains of Staph. aureus were employed in the current study: Staph. aureus ATCC 1131, ATCC 1210, ATCC 25923, and ATCC 439 (MicroBiologics Inc., St. Cloud, MN). Each culture was refreshed after thawing the frozen culture by streaking a loopful on BairdParker agar (BPA, Sigma-Aldrich, St. Louis, MO). The plates were incubated at $37^{\circ} \mathrm{C}$ for $18 \mathrm{~h}$. Next, one colony from each isolate was grown individually in brain-heart infusion (BHI) broth and incubated at $37^{\circ} \mathrm{C}$ for $18 \mathrm{~h}$. Three successive transfers were carried out to activate the culture for future experimental runs. The activated cultures were kept at $4^{\circ} \mathrm{C}$ and subcultured weekly during experimental periods. Meanwhile, a culture from $10 \mathrm{~mL}$ of $\mathrm{BHI}$ was centrifuged at 2,500 $\times g$ for 20 min to obtain pellets that were resuspended in $1 \mathrm{~mL}$ of sterile $0.1 \%$ peptone water. Then, the strain was used to inoculate milk samples at a final level of approximately $5 \log _{10} \mathrm{cfu} / \mathrm{mL}$.

\section{Screening of Staphylococcal Enterotoxin Production}

The production of staphylococcal enterotoxins in UHT milk containing 0,5 , or $10 \% \mathrm{NaCl}$ was tested after $0,1,3,7,14,21$, and $28 \mathrm{~d}$ of incubation at $37^{\circ} \mathrm{C}$ using VIDAS SET2 (bioMérieux SA, Marcy-l'Etoile, France). The VIDAS SET2 provided a direct method for screening food for the presence of any of the following enterotoxins: SEA, SEB, SEC1, SEC2, SEC3, SED, and SEE. VIDAS SET2 is composed of 30 reagent strips. All these compounds are ready for immediate use, except for the SET2 concentrated extraction buffer (R1), which requires further preparation by adding 1 $\mathrm{mL}$ of $\mathrm{R} 1$ to $55 \mathrm{~mL}$ of demineralized water $(1 \times 55$ $\mathrm{mL}$ ).

The abovementioned Staph. aureus strains were screened for the ability to produce staphylococcal enterotoxins in UHT milk. The UHT milk $(100 \mathrm{~mL})$ was inoculated separately with each Staph. aureus strain to a final level of approximately $5.0 \log _{10} \mathrm{cfu} / \mathrm{mL}$ and incubated at $37^{\circ} \mathrm{C}$ for $0,1,3,7,14,21$, and $28 \mathrm{~d}$. The enterotoxins were detected in UHT samples according to the manufacturer's protocol using an AOAC International (2007) method. Briefly, at specific time intervals, the $\mathrm{pH}$ of a $25-\mathrm{mL}$ UHT milk sample was adjusted to 3.5 to 4.0 using $5 \mathrm{~N} \mathrm{HCl}$. Then, the suspension was centrifuged for $15 \mathrm{~min}$ at 3,000 to $5,000 \times g$ at 18 to $25^{\circ} \mathrm{C}$ to recover the supernatant, and the residues were discarded. Subsequently, the $\mathrm{pH}$ of the supernatant was adjusted to 7.5 to 8.0 using $1 \mathrm{~N} \mathrm{NaOH}$, followed by 
centrifugation at 3,000 to $5,000 \times g$ for 15 min at 18 to $25^{\circ} \mathrm{C}$ to recover the supernatant. After filtration, 500 $\mu \mathrm{L}$ of the filtrate were placed in the sample well of a VIDAS SET2 reagent strip, and results were observed after $80 \mathrm{~min}$.

\section{Production of White-Brined Cheese}

White-brined cheese was prepared as described by Osaili et al. (2014) as illustrated in Figure 1. The experimental design of the current study is presented in Table 1. The full-fat cow milk was acquired from the dairy farm at Jordan University of Science and Technology (Ar-Ramtha, Jordan), pasteurized at $72^{\circ} \mathrm{C}$ for $15 \mathrm{~s}$, and cooled to 36 to $37^{\circ} \mathrm{C}$. The pasteurized milk was screened for the presence of Staph. aureus by taking aliquots $(100 \mu \mathrm{L})$ of pasteurized milk, which were surface-plated on BPA supplemented with egg yolk (Oxoid Ltd.), and incubated at $37^{\circ} \mathrm{C}$ for 24 to $48 \mathrm{~h}$. The pasteurized milk was observed to be negative for Staph. aureus. The pasteurized milk was divided into 15 -L batches for cheese making. The Staph. aureus strain ATCC 439 was added to yield an initial inoculum level of approximately 5.0 $\log _{10} \mathrm{cfu} / \mathrm{mL}$. In cheese treated with the starter culture, $0.5 \%$ (wt/vol) of a direct-to-vat thermophilic starter culture containing Streptococcus thermophilus and Lactobacillus delbrueckii ssp. bulgaricus (Danisco France, Paris, France) was added, and inoculated milk was kept at $37^{\circ} \mathrm{C}$ for $30 \mathrm{~min}$. Afterward, single-strength calf rennet (VGP Pharmachem, Vic, Spain) diluted 30-fold in double-distilled water was added to the pasteurized milk and kept at $37^{\circ} \mathrm{C}$ for 30 to $40 \mathrm{~min}$. The curd was cut into $2-\mathrm{cm}^{3}$ cubes using stainless steel knives, and whey was drained. Then, the curd was carefully transferred from the vat to a stainless steel mold with $50 \mathrm{~cm}$ $\times 50 \mathrm{~cm} \times 2 \mathrm{~cm}$ dimensions and pressed for $30 \mathrm{~min}$. The curd was cut manually into pieces that weighed 60 to $80 \mathrm{~g}$ and placed in sterilized glass jars containing either 10 or $15 \%$ sterilized $\mathrm{NaCl}$ brine solution, then stored at either $10^{\circ} \mathrm{C}$ or $25^{\circ} \mathrm{C}$. Samples from cheeses and brine solutions were taken at $0,1,3,7,14,21$, and 28 $\mathrm{d}$ of storage. Cheese making was repeated in triplicate, and 2 cheese loaves were taken from each experimental cheese to perform further analysis.

\section{Enumeration of Staph. aureus and Lactic Acid Bacteria}

A 25-g sample of internal section of white-brined cheese was homogenized with $225 \mathrm{~mL}$ of $(0.1 \%)$ peptone water for 2 min using a stomacher blender model 400 (Seward Ltd., London, UK). The sample from the brine solution was prepared by mixing $5 \mathrm{~mL}$ of brine solution with $45 \mathrm{~mL}$ of $0.1 \%$ peptone water and homogenized in a sterile stomacher bag for 2 min with the stomacher. Staphylococcus aureus were enumerated by surface plating of $100-\mu \mathrm{L}$ samples from the appropriate dilution on BPA supplemented with egg yolk (Oxoid Ltd.) and incubated at $37^{\circ} \mathrm{C}$ for 24 to $48 \mathrm{~h}$. Lactic acid bacteria (LAB) were enumerated by surface plating of $100 \mu \mathrm{L}$ of the appropriate dilution of cheese or brine sample on de Man Rogosa Sharpe agar (Thermo Scientific, Waltham, MA) and anaerobically incubated at $37^{\circ} \mathrm{C}$ for $48 \mathrm{~h}$.

\section{pH Measurement}

A pH meter equipped with glass body $\mathrm{pH}$ electrode for solid and semi-solid samples ECFG6351101B (Eutech Instrument, $\mathrm{pH}$ tutor, Singapore) was used to measure the $\mathrm{pH}$ values of white-brined cheese and brine solutions. The $\mathrm{pH}$ meter was calibrated with 3 buffers at $\mathrm{pH} 4,7$, and 10 . Then, the electrode was immersed in the white-brined cheese or brine until the reading became stable upon which $\mathrm{pH}$ values were recorded.

\section{Salt Determination by Silver Nitrate}

The concentration of $\mathrm{NaCl}$ in cheese was determined using the procedure as described by Osaili et al. (2014). Afterward, droplets $(\sim 0.5 \mathrm{~mL})$ of potassium chromate $\left(\mathrm{K}_{2} \mathrm{CrO}_{4}, 0.5 N\right)$ and $25 \mathrm{~mL}$ of distilled water were mixed thoroughly with ashed sample. The mixture was titrated against silver nitrate $\left(\mathrm{AgNO}_{3}, 0.05 \mathrm{~N}\right)$ until a brown color developed. The salt concentration was calculated using the following equation:

$$
\begin{gathered}
\text { Salt content } \%=\left(\text { titrated volume of } \mathrm{AgNO}_{3}\right. \\
\times 0.00292) / \text { weight }(\mathrm{g}) \times 100 \% .
\end{gathered}
$$

\section{Water Activity Measurement of Cheese}

A sample of approximately $2 \mathrm{~g}$ from a cross-sectional piece of white-brined cheese was placed in a water activity meter (Hygrolab, Rotronic Instr. Corp., Huntington, NY) to measure the $a_{w}$.

\section{Staphylococcal Enterotoxin Detection for White-Brined Cheese}

A cheese sample $(25 \mathrm{~g})$ was added to $40 \mathrm{~mL}$ of demineralized water pre-incubated at 35 to $40^{\circ} \mathrm{C}$. Afterward, the same steps outlined in the section for screening of staphylococcal enterotoxin production in broth were 


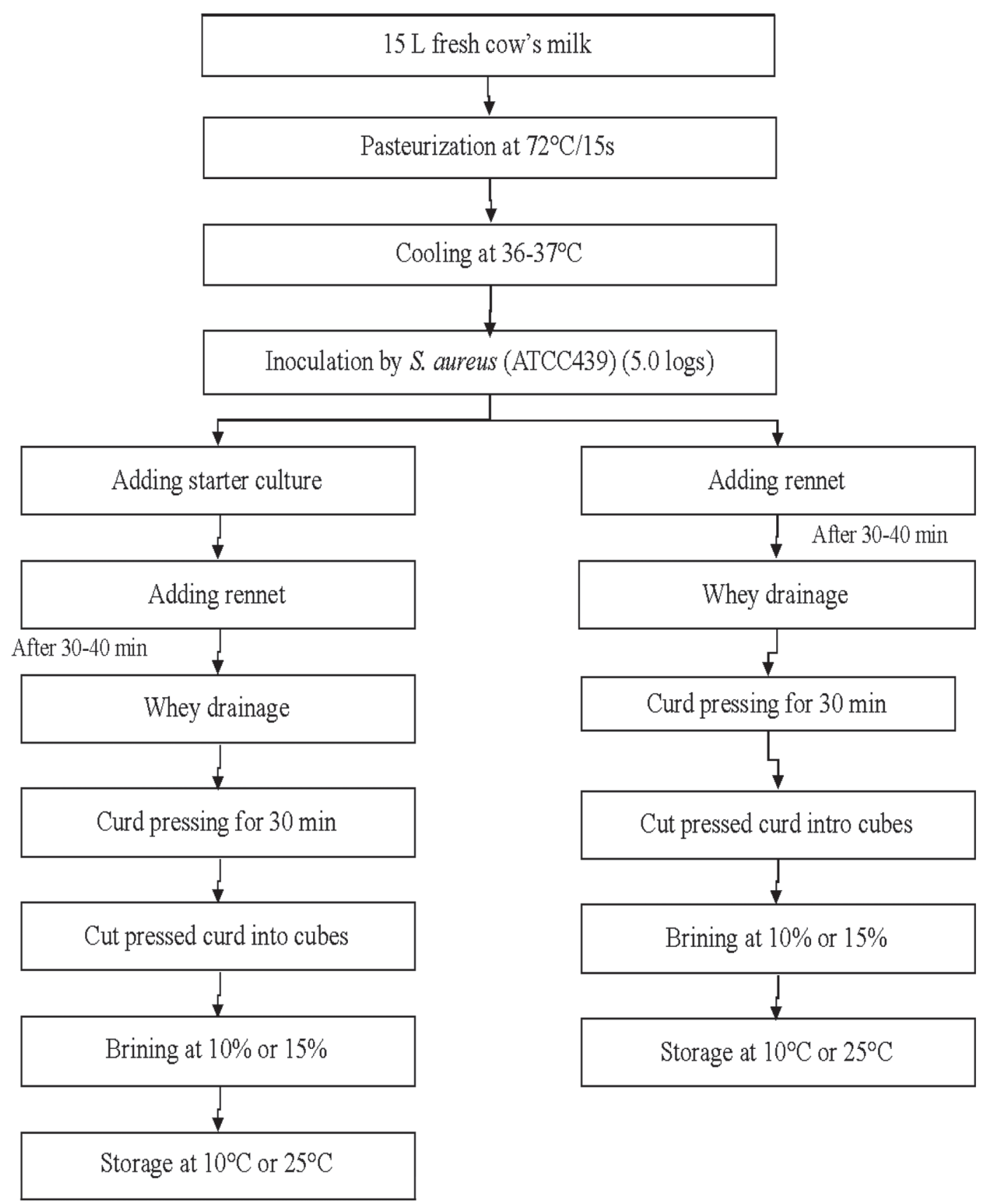

Figure 1. Preparation of white-brined cheese with or without a starter culture and stored in a 10 or $15 \%$ NaCl brine at $10^{\circ} \mathrm{C}$ and $25^{\circ} \mathrm{C}$ for 28 d. S. aureus $=$ Staphylococcus aureus.

followed to detect the presence of enterotoxins in whitebrined cheese.

\section{Statistical Analysis}

Effects of $\mathrm{NaCl}$ concentration, storage temperature, and the presence or absence of the starter culture on staphylococcal growth and enterotoxin production in white-brined cheese were analyzed using SPSS software version 19.0 (IBM Corp., Armonk, NY). The independent samples $t$-test was used to compare 2 levels of temperature. One-way ANOVA was performed to examine the effect of the variables $\mathrm{NaCl}$ concentration, storage time, and the presence or absence of starter culture. The Duncan post hoc test was used to determine the difference between variables groups. A $P$-value of $<0.05$ was considered the cutoff level for statistical significance. 
Table 1. Experimental design for growth of Staphylococcus aureus in white-brined cheese

\begin{tabular}{lllll}
\hline & $\begin{array}{l}\text { Staph } \\
\text { aureus }\end{array}$ & $\begin{array}{l}\text { Starter } \\
\text { culture }\end{array}$ & $\begin{array}{l}\mathrm{NaCl} \\
(\%)\end{array}$ & $\begin{array}{l}\text { Storage } \\
\text { temperature } \\
\left({ }^{\circ} \mathrm{C}\right)\end{array}$ \\
\hline 1 & + & + & 10 & 10 \\
2 & + & - & 10 & 10 \\
3 & + & + & 10 & 25 \\
4 & + & - & 10 & 25 \\
5 & + & + & 15 & 10 \\
6 & + & - & 15 & 10 \\
7 & + & + & 15 & 25 \\
8 & + & - & 15 & 25 \\
\hline
\end{tabular}

\section{RESULTS}

\section{Screening for Staphylococcal Enterotoxins}

We investigated production of staphylococcal enterotoxins by different Staph. aureus strains inoculated in UHT milk containing 0,5 , or $10 \% \mathrm{NaCl}$ incubated at $37^{\circ} \mathrm{C}$. Among the tested strains, only Staph. aureus ATCC 439 produced enterotoxin in UHT milk without $\mathrm{NaCl}$ at $\mathrm{d} 1,3$, and 7 , at concentrations of $0.72,0.33$, and $0.27 \mathrm{IU}$, respectively, However, the toxin was not detected beyond $7 \mathrm{~d}$ (Table 2). Although the initial numbers of Staph. aureus in UHT milk $(\sim 5.5 \log \mathrm{cfu} / \mathrm{g})$ increased, reaching $>8 \log \mathrm{cfu} / \mathrm{g}$, no strains could produce enterotoxins in UHT milk containing 5 or $10 \%$ $\mathrm{NaCl}$. It is worth mentioning that enterotoxins were also not detected in white-brined cheese at different storage times and temperatures as described in the section below (results not shown).

\section{Behavior of Staph. aureus in Cheese and Brine Solution}

Tables 3 and 4 present the Staph. aureus populations in white-brined cheeses and brine solutions, respectively, during storage for 28 d. Growth of Staph. aureus was noted in white-brined cheese stored in $10 \%$ or $15 \%$ $\mathrm{NaCl}$ brine solution at $10^{\circ} \mathrm{C}$ or $25^{\circ} \mathrm{C}$ produced with or without starter culture (Table 3). In general, the increase in the numbers of Staph. aureus in cheese and brine fluctuated during storage; however, at d 28, the numbers increased significantly $(P<0.05)$ compared with the initial inoculation level.

White cheese produced without starter culture and stored in $10 \% \mathrm{NaCl}$ at $25^{\circ} \mathrm{C}(\mathrm{T} 4)$ showed the highest $(P$ $<0.05)$ growth of Staph. aureus with numbers increasing from 5.41 to $8.39 \log _{10} \mathrm{cfu} / \mathrm{g}$ after $28 \mathrm{~d}$. However, cheese produced with the starter culture and stored in $15 \% \mathrm{NaCl}$ at $10^{\circ} \mathrm{C}(\mathrm{T} 5)$ showed the lowest increase in the numbers of Staph. aureus after $28 \mathrm{~d}$. The numbers of Staph. aureus increased from $4.88 \log _{10} \mathrm{cfu} / \mathrm{g}$ during

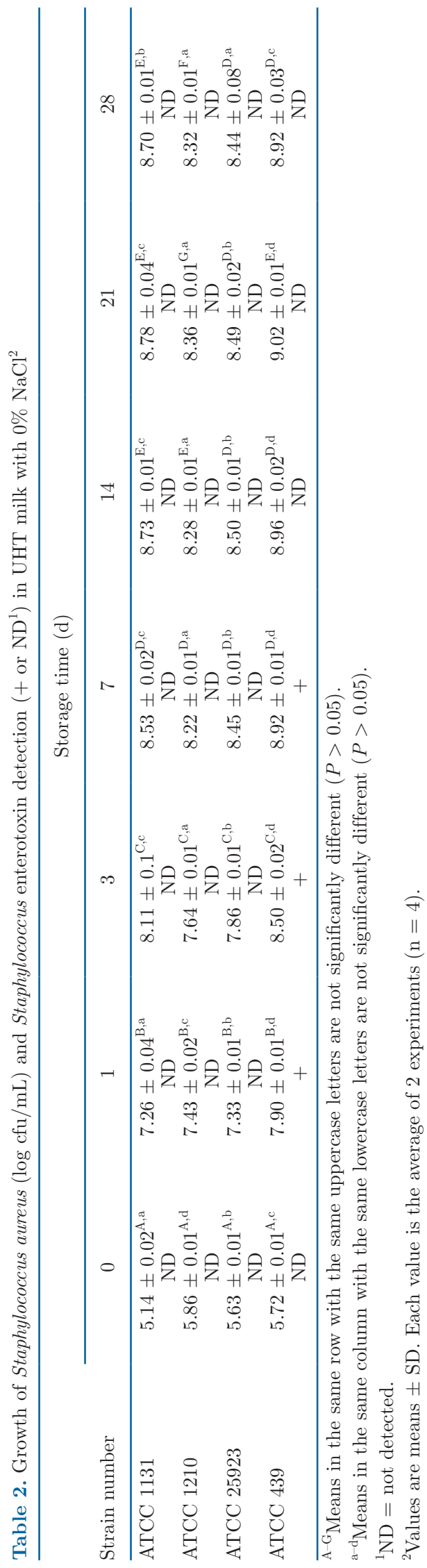



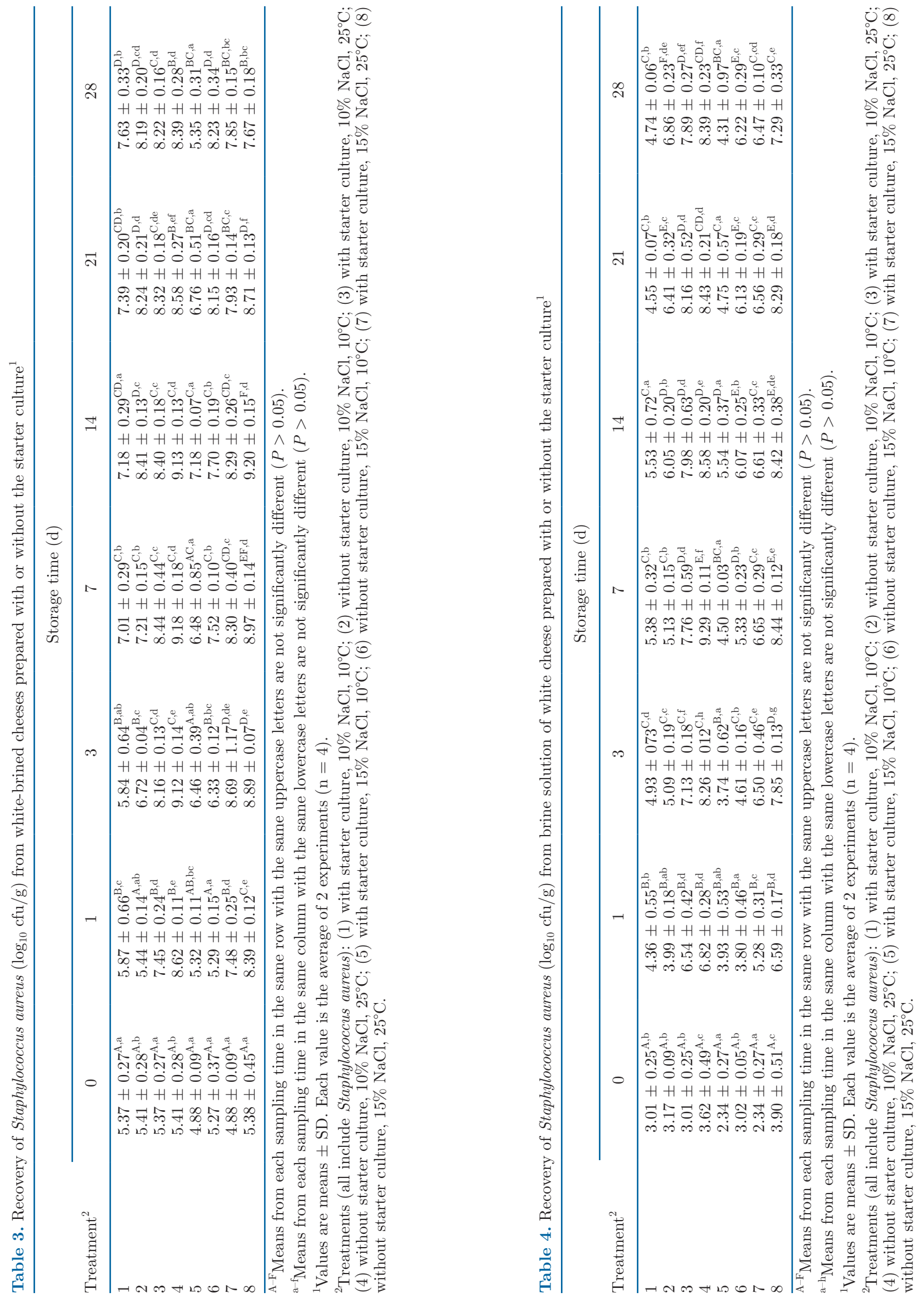
the first $14 \mathrm{~d}$ of storage to reach $7.18 \log _{10} \mathrm{cfu} / \mathrm{g}$, but viability decreased until the end of the storage period to $5.35 \log _{10} \mathrm{cfu} / \mathrm{g}$. The effect of different treatments on the growth of Staph. aureus in cheese was inconsistent among all treatments. At $10^{\circ} \mathrm{C}$, in the absence of the starter culture, the growth of Staph. aureus significantly increased $(P<0.05)$ in $10 \%$ and $15 \% \mathrm{NaCl}$ by 2.78 and $2.96 \log _{10} \mathrm{cfu} / \mathrm{g}$, respectively, compared with the initial inoculum level (Table 3). Furthermore, at $10^{\circ} \mathrm{C}$ the growth of Staph. aureus in the presence of starter culture increased in cheese stored in $15 \%$ and $10 \% \mathrm{NaCl}$ brine solution by 0.47 and $2.26 \log _{10} \mathrm{cfu} / \mathrm{g}$, respectively. However, the effect of starter culture on growth was inconsistent and not significant at $25^{\circ} \mathrm{C}$ (Table 3). Moreover, the growth of Staph. aureus was higher $(P<0.05)$ in cheese stored in $10 \% \mathrm{NaCl}$ compared with growth at $15 \% \mathrm{NaCl}$. For instance, the growth in cheese stored in $10 \% \mathrm{NaCl}$ at $10^{\circ} \mathrm{C}$ with starter culture (T1) was higher than the growth in cheese stored in $15 \% \mathrm{NaCl}$ at $10^{\circ} \mathrm{C}$ with starter culture (T5). The final variable investigated was temperature. Staphylococcus aureus generally grew more in higher temperatures. For example, cheese stored in $10 \% \mathrm{NaCl}$ at $25^{\circ} \mathrm{C}$ with the starter culture (T3) had a higher Staph. aureus population compared with cheese stored at $10^{\circ} \mathrm{C}(\mathrm{T} 1)$.

Staphylococcus aureus cells directly contaminated the sterile brine solutions in which they were stored, because approximately $3.0 \log _{10} \mathrm{cfu} / \mathrm{mL}$ (ranging from 1.9-4.1 $\log _{10} \mathrm{cfu} / \mathrm{mL}$ ) was recovered directly after immersion of cheese in the brine solution (Table 4). The growth of Staph. aureus in the brine solution increased $(P<0.05)$ in all treatments during the storage period. Similar trends were observed in brine where the maximum growth occurred in $10 \%$ brine solution stored at $25^{\circ} \mathrm{C}$ without the starter culture $\left(3.62-8.39 \log _{10}\right.$ $\mathrm{cfu} / \mathrm{mL}$ ), whereas the minimum growth was noted in $15 \%$ brine solution stored at $10^{\circ} \mathrm{C}$ with starter culture (2.34-4.31 $\log _{10} \mathrm{cfu} / \mathrm{mL}$; Table 4). The effect of different treatments on the growth of Staph. aureus in brine was that the starter culture and salt reduced the growth, whereas greater temperature enhanced it.

\section{Growth of LAB in Cheese and Brine Solution}

Table 5 shows the numbers of LAB (starter and nonstarter) in white-brined cheese, and Table 6 shows the numbers of LAB in the brine solution. Starter and nonstarter LAB numbers increased by 0.35 to $3.24 \log _{10}$ $\mathrm{cfu} / \mathrm{g}$ in white cheese stored in 10 or $15 \% \mathrm{NaCl}$ brine after $28 \mathrm{~d}$ at $10^{\circ} \mathrm{C}$ or $25^{\circ} \mathrm{C}$ (Table 5). Likewise, the numbers of starter and non-starter LAB in the brine solutions increased by 0.45 to $5.06 \log _{10} \mathrm{cfu} / \mathrm{mL}$ by 28 d at $10^{\circ} \mathrm{C}$ or $25^{\circ} \mathrm{C}$ (Table 6). The increase in viability of
LAB was significant $(P<0.05)$ up to d 14 ; afterward, the counts were maintained or slightly decreased $(P$ $>0.05)$ until the end of storage time. The maximum growth was evident in samples stored in $10 \% \mathrm{NaCl}$ at $10^{\circ} \mathrm{C}$ without starter culture $\left(\mathrm{T} 4 ; 8.24 \log _{10} \mathrm{cfu} / \mathrm{g}\right.$ in cheese and $8.20 \log _{10} \mathrm{cfu} / \mathrm{mL}$ in brine), while the minimum growth occurred in samples stored in $15 \% \mathrm{NaCl}$ at $10^{\circ} \mathrm{C}$ with the starter culture $\left(\mathrm{T} 5 ; 5.28 \log _{10} \mathrm{cfu} / \mathrm{g}\right.$ in cheese and $2.78 \log _{10} \mathrm{cfu} / \mathrm{mL}$ in brine). We observed that the starter culture suppressed the growth of Staph. aureus in cheese. As shown in Table 5, the LAB count was lower in cheese stored in $10 \% \mathrm{NaCl}$ at $10^{\circ} \mathrm{C}$ with the starter culture (T1) than the count in cheese stored in $10 \% \mathrm{NaCl}$ at $10^{\circ} \mathrm{C}$ without the starter culture (T2). Furthermore, the growth of LAB was higher in cheese stored in $10 \% \mathrm{NaCl}$ compared with growth at $15 \%$. For instance, the LAB population in cheese stored in $10 \%$ $\mathrm{NaCl}$ at $10^{\circ} \mathrm{C}$ with the starter culture (T1) was higher than the LAB population in cheese stored in $15 \% \mathrm{NaCl}$ at $10^{\circ} \mathrm{C}$ with the starter culture (T5; Table 5). On the contrary, temperature positively affected growth; LAB grew more in higher temperatures. For example, cheese stored in $10 \% \mathrm{NaCl}$ at $25^{\circ} \mathrm{C}$ (T3) had higher numbers of $\mathrm{LAB}$ compared with cheese stored in $10 \% \mathrm{NaCl}$ at $10^{\circ} \mathrm{C}(\mathrm{T} 1)$. Based on these data, LAB counts were affected positively by lower salt concentration and higher temperatures.

\section{Salt Concentration, $\mathrm{pH}$, and Water Activity of Cheese}

The $\mathrm{pH}$ values of the white-brined cheeses produced with the starter culture were lower $(P<0.05)$ than those of cheeses produced without the starter culture (Table 7). Table 7 shows that the initial $\mathrm{pH}$ of whitebrined cheeses produced with the starter culture was approximately 5.66 and dropped to 5.16-5.33 after 28 $\mathrm{d}$ of storage. However, the initial $\mathrm{pH}$ of white-brined cheeses produced without the starter culture was 6.72 and dropped to 5.41 to 6.31 after $28 \mathrm{~d}$ of storage (Table 7). The salt concentration in white-brined cheese at 1 $\mathrm{d}$ in 10 and $15 \% \mathrm{NaCl}$ solution was 4.73 to $4.99 \%$ and 6.04 to $6.45 \% \mathrm{NaCl}$ (wt/wt), respectively. After $28 \mathrm{~d}$ of storage, a slight change occurred in the white-brined cheeses stored in $10 \% \mathrm{NaCl}$, whereas the salt content of cheese samples stored in $15 \%$ brine increased by $1.27 \%$ to $2.16 \%$ (Table 8 ).

There was a decrease in $\mathrm{a}_{\mathrm{w}}$ of cheese in all treatments in a range from 0.06 to 0.11 at $\mathrm{d} 28$ (Table 9). The $\mathrm{a}_{\mathrm{w}}$ was less than optimal in all treatments at all storage times for Staph. aureus growth and SE production, which is 0.98 , according to (Tatini, 1973). In addition, the $\mathrm{a}_{\mathrm{w}}$ was higher for cheese in $10 \% \mathrm{NaCl}$ compared with $15 \% \mathrm{NaCl}$, at $10^{\circ} \mathrm{C}$ compared with $25^{\circ} \mathrm{C}$, and in 

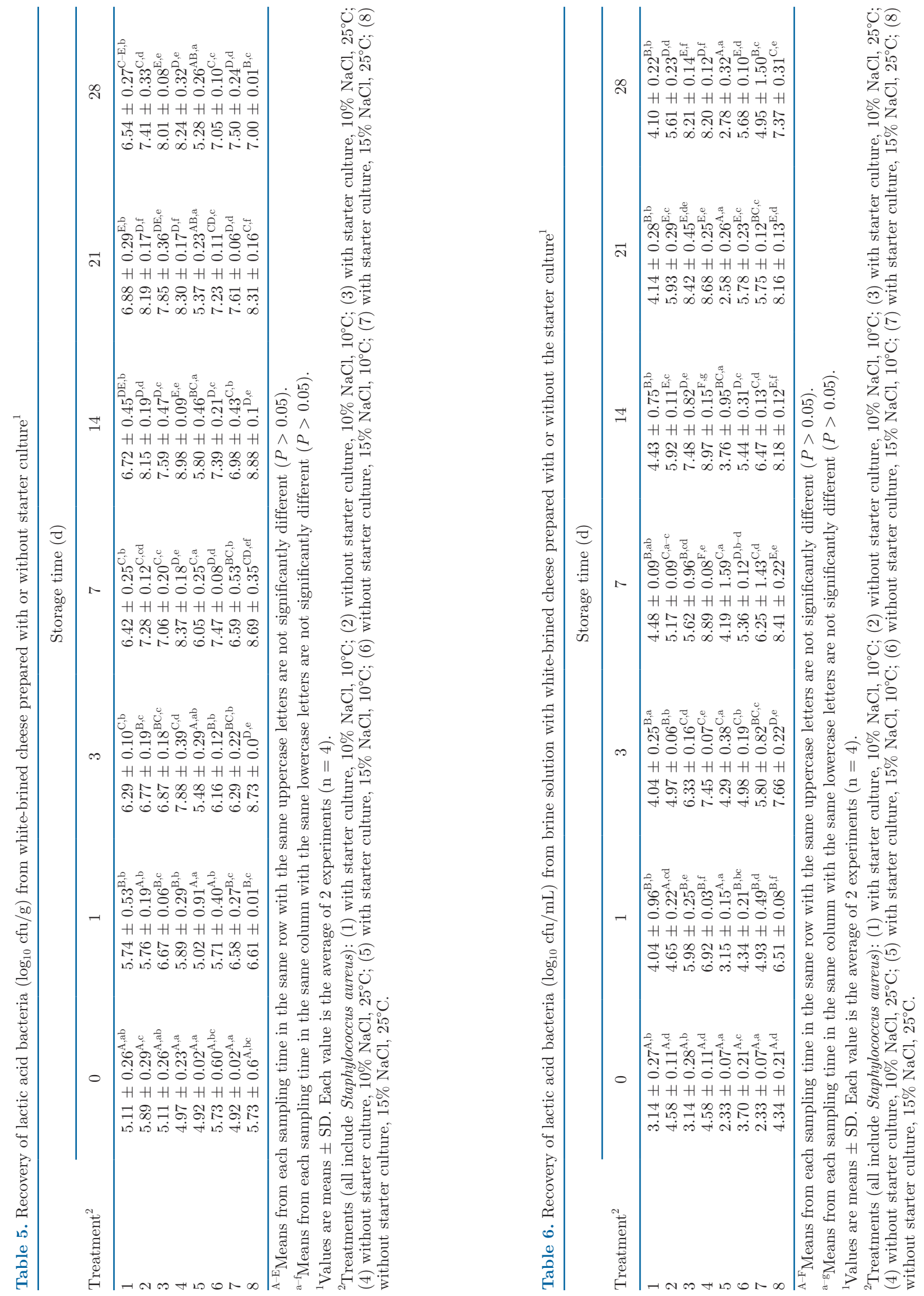

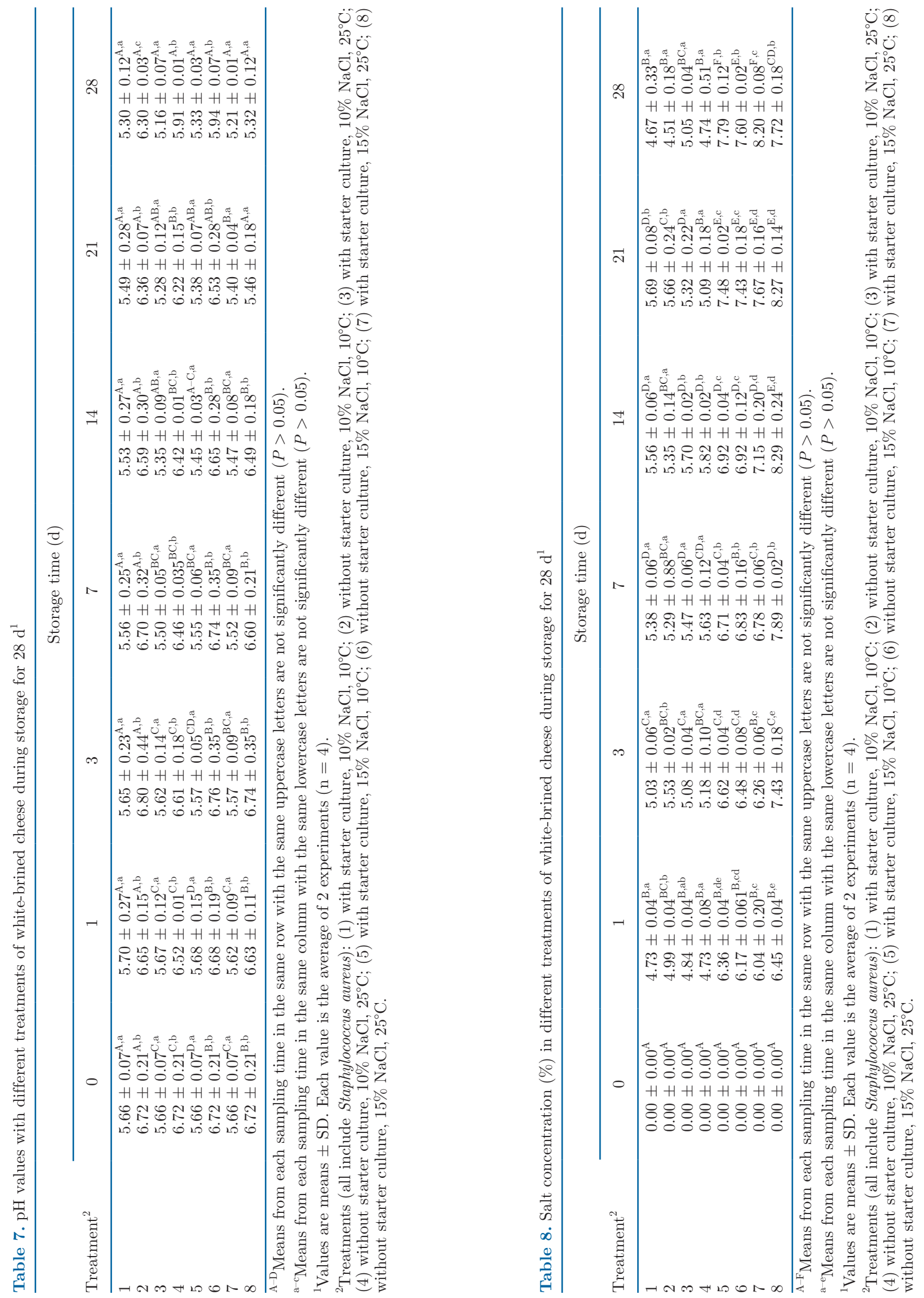

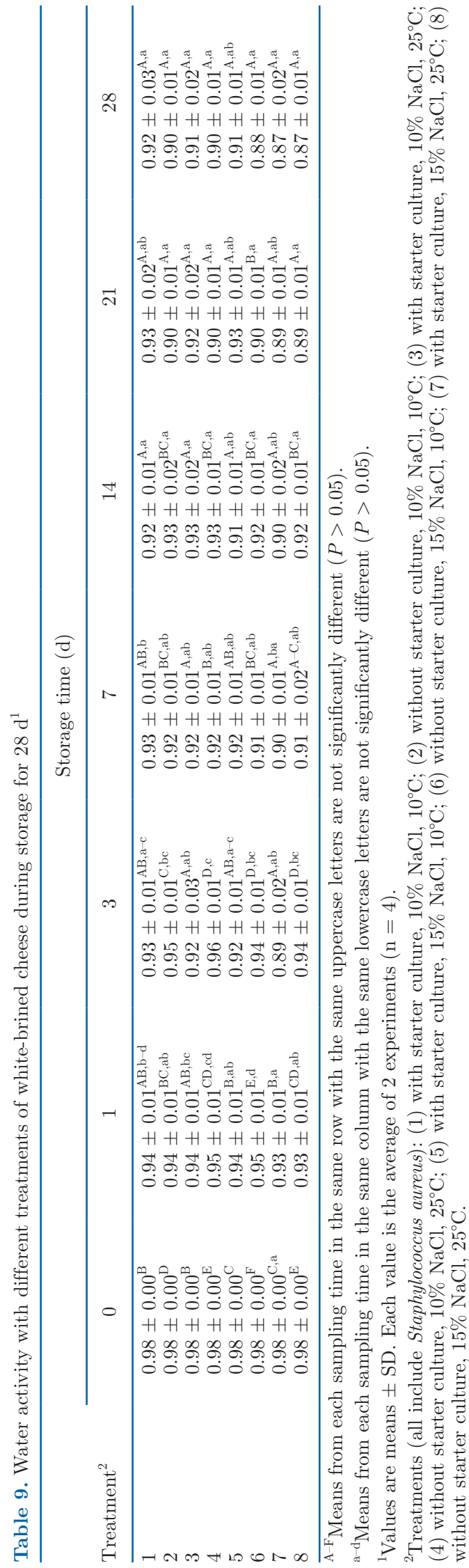

the presence of the starter culture compared with its absence (Table 9).

\section{DISCUSSION}

In the current study, we noted that all Staph. aureus strains grew in UHT milk containing 0,5 , and $10 \% \mathrm{NaCl}$ at $37^{\circ} \mathrm{C}$ and did not produce any enterotoxins; however, strain ATCC 439 produced enterotoxins in UHT milk without $\mathrm{NaCl}$ during the first $7 \mathrm{~d}$ of storage. No enterotoxins were detected in any experimental white-brined cheeses (data not shown). This suggested that Staph. aureus ATCC 439 did not produce enterotoxins during growth in the experimental cheeses. Production of enterotoxins is genetically regulated; thus, strains that cannot produce enterotoxins may not harbor the specific gene to express enterotoxins (Bystron et al., 2006). These results supported Bystron et al. (2006), who reported that 32 of the 99 examined Staph. aureus strains were found to be enterotoxin producers. Atanassova et al. (2001) found that $28.6 \%$ of Staph. aureus strains isolated from fresh meat were enterotoxigenic and harbored one or more enterotoxin genes. Furthermore, the environmental growth conditions such as low $\mathrm{pH}$, presence of $\mathrm{LAB}$, and salt concentration may affect expression of staphylococcal enterotoxin genes. Similarly, Novick (2003) found that the presence of $1.0 \mathrm{M}$ $\mathrm{NaCl}$ or a sub-inhibitory concentration of clindamycin reduced the transcription of sae, the virulence regulator of Staph. aureus, which is responsible for enterotoxin production.

Therefore, the production of enterotoxins is not necessarily associated with staphylococcal growth, especially in food. Staphylococcus aureus growth and enterotoxin production depend on different factors such as the presence of starter culture, the temperature, salt content, $\mathrm{pH}$ values, $\mathrm{a}_{\mathrm{w}}$, atmospheric pressure, and nutritional factors (Valero et al., 2009). There is a difference in the optimal temperatures required for growth and production of enterotoxins, which are $37^{\circ} \mathrm{C}$ and $40^{\circ} \mathrm{C}$ to $45^{\circ} \mathrm{C}$, respectively. Similarly, staphylococcal enterotoxins were not detected in Iranian ultra-filtered white cheese stored at $8^{\circ} \mathrm{C}$ and $25^{\circ} \mathrm{C}$. This was attributed to the inhibitory effect of the starter culture on the growth of Staph. aureus and enterotoxin production (Mohammadi and Hanifian, 2015). Similar to our findings, Viçosa et al. (2019) detected enterotoxins in their experimental broth (model medium) and but not in fresh cheeses.

The present study demonstrated that the numbers of Staph. aureus ATCC 439 increased significantly in all treatments, with a higher growth rate in cheese produced without the starter culture and stored in $10 \%$ $\mathrm{NaCl}$ at $25^{\circ} \mathrm{C}$. Moreover, a reduced growth rate was noted in cheese produced with the starter culture and 
stored in $15 \% \mathrm{NaCl}$ at $10^{\circ} \mathrm{C}$ after $28 \mathrm{~d}$. The reduced growth rate may be explained by the reduced $\mathrm{pH}$ of 5.66 in cheese produced with the starter culture compared with the $\mathrm{pH}$ of 6.72 in cheese without the starter culture. This is consistent with many previous reports which found that the viability of Staph. aureus ATCC 439 was reduced in different dairy products following inoculation with the starter cultures (Stecchini et al., 1991; Arqués et al., 2006; Adhikari et al., 2018). The inhibitory effect of the starter culture may be due to the drop in $\mathrm{pH}$ as a result of lactic acid production and to other metabolites, such as antibiotic substances and the production of hydrogen peroxide (Vernozy-Rozand et al., 1998; Alomar et al., 2008; Le Marc et al., 2009). The inconsistent effect of the starter culture on Staph. aureus ATCC 439 in experimental cheeses stored at $25^{\circ} \mathrm{C}$ may be attributed to the ability of Staph. aureus to resist starter culture influence on $\mathrm{pH}$ change and nutrient availability and grow in the cheeses stored at $25^{\circ} \mathrm{C}$ compared with $10^{\circ} \mathrm{C}$.

Salt has 3 primary functions in cheese: it acts as a preservative, enhances safety, and contributes directly to salty flavor (Fox et al., 2017). As previously mentioned, Staph. aureus has the potential to survive in concentrations of up to $15 \% \mathrm{NaCl}$ (Elahi and Fujikawa, 2019b). In the present study, Staph. aureus ATCC 439 grew in salt concentrations of $10 \%$ and $15 \%$ due to its halotolerant nature. Furthermore, the growth was lower in $15 \% \mathrm{NaCl}$ compared with the growth in $10 \%$ $\mathrm{NaCl}$. Such behavior of Staph. aureus ATCC 439 was expected on the basis of similar results being reported in several previous studies. Elahi and Fujikawa (2019a) also reported that the increase in $\mathrm{NaCl}$ concentration reduced Staph. aureus growth, where $5 \% \mathrm{NaCl}$ had little effect, whereas concentrations of 10 to $20 \%$ showed an apparent inhibitory effect against the organisms.

The growth rate of Staph. aureus ATCC 439 in cheese or brine solution in the present study was higher at $25^{\circ} \mathrm{C}$ compared with $10^{\circ} \mathrm{C}$. Similarly, Mohammadi and Hanifian (2015) found that the Staph. aureus numbers in the cheese stored at $25^{\circ} \mathrm{C}$ were higher than those stored at $8^{\circ} \mathrm{C}$. Moreover, a combined effect of temperature and $\mathrm{NaCl}$ on the growth of Staph. aureus ATCC 439 was observed in this study. This was supported by the results reported by Elahi and Fujikawa (2019a), who have reported that the growth of Staph. aureus boundaries in BHI increased with a temperature increase and limited with salt concentration. Our findings revealed that higher $\mathrm{NaCl}$ concentration negatively affected the growth of Staph. aureus in cheese or brine keeping solution, whereas the growth was positively influenced by higher temperature. Therefore, white-brine cheese should be stored in $\mathrm{NaCl}$ concentrations higher than $15 \%$ at refrigerated temperatures.
Starter and non-starter LAB are responsible for the production of lactic acid, which decreases the $\mathrm{pH}$ of the curd and whey. Lactic acid production is directly proportional to the increase in LAB numbers. In contrary with the results of this study, LAB growth was higher in samples produced with the starter culture of Iranian ultra-filtered white cheese (Mohammadi and Hanifian, 2015), Feta-type cheese (Madureira et al., 2011), and batches of sausage (Essid and Hassouna, 2013). According to previous studies, the growth of the starter LAB during cheese manufacture increased within $1 \mathrm{~d}$, dominating the microflora of cheese during ripening. Subsequently, the majority dies off and lyses relatively rapidly. The growth of starter LAB is negatively influenced by $\mathrm{NaCl}$ concentration (Fox et al., 2017), which is reflected in the results of this study, where $15 \% \mathrm{NaCl}$ had lower LAB counts. Non-starter LAB are found in high numbers $\left(>10^{8} \mathrm{cfu} / \mathrm{g}\right)$ in all freshly made cheese. Within the first few weeks of ripening, non-starter LAB grow relatively quickly to high numbers $\left(\sim 10^{8} \mathrm{cfu} / \mathrm{g}\right)$; however, they lyse very slowly in cheese. Their growth depends on the ripening temperature, which supports the higher LAB count noted at higher temperatures in this study. Moreover, the tolerance of non-starter LAB to salt and acid, and their ability to grow in the absence of oxygen implies that they should grow well in cheese. In contrast, starter LAB are sensitive to salt; therefore, they are not expected to survive in salted cheese (Fox et al., 2017). Although non-starter LAB grew in minimal amounts in pasteurized milk, they could grow in white cheese and might affect its quality, either positively or negatively. Therefore, LAB are considered a major uncontrolled factor in white cheese manufacture (Crow et al., 2001; Briggiler-Marcó et al., 2007).

The $\mathrm{pH}$ values obtained in this study were typical of soft white-brined cheese (Osaili et al., 2014). One of the most effective factors to inhibit the growth of Staph. aureus is to acidify the cheese by the addition of starter cultures (Turhan and Kaletunc, 1992; Medved'ová et al., 2009). That was evident in the results of this study, where $\mathrm{pH}$ values were lower in the presence of the starter culture compared with its absence. Results from another study by Erkmen (1995) supported this observation; $\mathrm{pH}$ was lower in the presence of Streptococcus cremoris in the Turkish Feta cheese examined. In the present study, the $\mathrm{pH}$ values of both cheese and brine were lower at lower $\mathrm{NaCl}$ concentrations. This was expected because the higher salt level affected LAB growth, microbial lactose metabolism, and the development of proteolytic and lipolytic activities during ripening (Osaili et al., 2012). The drop in $\mathrm{pH}$ in cheeses produced without starter culture may be attributed to organic acids produced by non-starter culture 
LAB. Similar results have been reported by Osaili et al. (2014).

In brine-salted cheeses, $\mathrm{NaCl}$ concentration is influenced by the concentration of salt in the brine, temperature, and time immersed in the brine solution (Fox et al., 2017). The average salt content in this study increased $(P<0.05)$ after $1 \mathrm{~d}$ of storage. The increase in salt content was greater $(P<0.05)$ in cheeses brined in $15 \% \mathrm{NaCl}$ compared with $10 \% \mathrm{NaCl}$. Likewise, it increased in Turkish Feta cheese from $6.77 \%$ to $7.88 \%$ during the storage period (Erkmen, 1995). The salt content likely increased in cheese, whereas the moisture content decreased during storage time due to the net movement of $\mathrm{Na}^{+}$and $\mathrm{Cl}^{-}$from the brine into the cheese as a consequence of the difference in osmotic pressure between the brine and the moisture phase of the cheese, both as a result of dehydration (Erkmen, 1995; Fox et al., 2017). The $\mathrm{a}_{\mathrm{w}}$ of food depends on its moisture content and the concentration of salt (Fox et al., 2017). The relationship between $\mathrm{NaCl}$ concentration and $\mathrm{a}_{\mathrm{w}}$ on the growth of Staph. aureus is inversely proportional. That is, increased concentration of $\mathrm{NaCl}$ decreases the $\mathrm{a}_{\mathrm{w}}$, thereby decreasing the growth of Staph. aureus and SE production. This is most likely due to differences in moisture and salt content between the different concentrations of $\mathrm{NaCl}$ (Ibrahim et al., 1981; Notermans and Heuvelman, 1983). In conclusion, brine solution and storage temperature had major effects on Staph. aureus growth in the white-brined cheese. Enterotoxin production by Staph. aureus ATCC 439 was inhibited in stored white-brined cheese. Nonetheless, it is highly recommended that the best hygienic manufacturing practices and storage conditions be maintained to control the growth of Staph. aureus in case of contamination.

\section{ACKNOWLEDGMENTS}

The authors thank Jordan University of Science and Technology (grant No. 167/2017), United Arab Emirates University (grant no. 31F135) and Jordan Food and Drug Administration for funding this project. The authors have not stated any conflicts of interest.

\section{REFERENCES}

Abdel-Hameid Ahmed, A., N. M. Saad Maharik, A. Valero, and S. M. Kamal. 2019. Incidence of enterotoxigenic Staphylococcus aureus in milk and Egyptian artisanal dairy products. Food Control 104:20-27. https://doi.org/10.1016/j.foodcont.2019.04.017.

Adhikari, A., V. K. Yemmireddy, M. J. Costello, P. M. Gray, R. Salvadalena, B. Rasco, and K. Killinger. 2018. Effect of storage time and temperature on the viability of E. coli O157: H7, Salmonella spp., Listeria innocua, Staphylococcus aureus, and Clostridium sporogenes vegetative cells and spores in vacuum-packed canned pasteurized milk cheese. Int. J. Food Microbiol. 286:148-154. https:// doi.org/10.1016/j.ijfoodmicro.2018.07.027.
Al-Holy, M. A., A. Al-Nabulsi, T. M. Osaili, M. M. Ayyash, and R. R. Shaker. 2012. Inactivation of Listeria innocua in brined white cheese by a combination of nisin and heat. Food Control 23:48-53. https://doi.org/10.1016/j.foodcont.2011.06.009.

Alomar, J., A. Lebert, and M. C. Montel. 2008. Effect of temperature and $\mathrm{pH}$ on growth of Staphylococcus aureus in co-culture with Lactococcus garvieae. Curr. Microbiol. 56:408-412. https://doi.org/10 .1007/s00284-007-9079-3.

AOAC International. 2007. Official Methods of Analysis of AOAC International. 18th ed. W. Horwitz and G. Latimer, ed. Vol. 534. AOAC International, Arlington, VA.

Arqués, J. L., S. Garde, P. Gaya, M. Medina, and M. Nuñez. 2006. Inactivation of microbial contaminants in raw milk La Serena cheese by high-pressure treatments. J. Dairy Sci. 89:888-891. https://doi .org/10.3168/jds.S0022-0302(06)72153-1.

Atanassova, V., A. Meindl, and C. Ring. 2001. Prevalence of Staphylococcus aureus and staphylococcal enterotoxins in raw pork and uncooked smoked ham - a comparison of classical culturing detection and RFLP-PCR. Int. J. Food Microbiol. 68:105-113. https:// doi.org/10.1016/S0168-1605(01)00479-2.

Ayyash, M. M., and N. Shah. 2011. The effect of substituting $\mathrm{NaCl}$ with $\mathrm{KCl}$ on Nabulsi cheese: Chemical composition, total viable count, and texture profile. J. Dairy Sci. 94:2741-2751. https://doi .org $/ 10.3168 /$ jds.2010-3976.

Ayyash, M. M., F. Sherkat, and N. Shah. 2013. Sodium chloride substitution of cheese. Pages 545-566 in Handbook of Cheese in Health: Production, Nutrition and Medical Sciences. V. R. Preedy, R. R. Watson, and V. B. Patel, ed. Wageningen Academic Publishers, Wageningen, Netherlands.

Briggiler-Marcó, M., M. L. Capra, A. Quiberoni, G. Vinderola, J. A. Reinheimer, and E. Hynes. 2007. Nonstarter Lactobacillus strains as adjunct cultures for cheese making: In vitro characterization and performance in two model cheeses. J. Dairy Sci. 90:4532-4542. https://doi.org/10.3168/jds.2007-0180.

Bystron, J., J. Bania, A. Zarczynska, K. Korzekwa, J. Molenda, and K. Kosek-Paszkowska. 2006. Detection of enterotoxigenic Staphylococcus aureus strains using a commercial ELISA and multiplexPCR. Bull. Vet. Inst. Pulawy 50:329-333.

Cebrián, G., P. Mañas, and S. Condón. 2016. Comparative resistance of bacterial foodborne pathogens to non-thermal technologies for food preservation. Front. Microbiol. 7:734. https://doi.org/10 $.3389 /$ fmicb.2016.00734.

Coton, E., M. H. Desmonts, S. Leroy, M. Coton, E. Jamet, S. Christieans, P. Y. Donnio, I. Lebert, and R. Talon. 2010. Biodiversity of coagulase-negative staphylococci in French cheeses, dry fermented sausages, processing environments and clinical samples. Int. J. Food Microbiol. 137:221-229.

Crow, V., B. Curry, and M. Hayes. 2001. The ecology of non-starter lactic acid bacteria (NSLAB) and their use as adjuncts in New Zealand Cheddar. Int. Dairy J. 11:275-283. https://doi.org/10 .1016/S0958-6946(01)00057-7.

Dayan, G. H., N. Mohamed, I. L. Scully, D. Cooper, E. Begier, J. Eiden, K. U. Jansen, A. Gurtman, and A. S. Anderson. 2016. Staphylococcus aureus: The current state of disease, pathophysiology and strategies for prevention. Expert Rev. Vaccines 15:1373-1392. https://doi.org/10.1080/14760584.2016.1179583.

de Oliveira, A. P. D., M. M. da Costa, D. M. Nogueira, and F. S. Dias. 2019. Characterisation of Staphylococcus aureus strains from milk and goat cheese and evaluation of their inhibition by gallic acid, nisin, and velame of the Brazilian caatinga. Int. J. Dairy Technol. $70: 1-12$

Dewey-Mattia, D., K. Manikonda, A. J. Hall, M. E. Wise, and S. J. Crowe. 2018. Surveillance for foodborne disease outbreaks-United States, 2009-2015. MMWR Surveill. Summ. 67:1-11. https:// doi.org/10.15585/mmwr.ss6710a1.

EFSA (European Food Safety Authority). 2018. The European Union summary report on trends and sources of zoonoses, zoonotic agents and food-borne outbreaks in 2017. EFSA J. 16:5500.

Elahi, S., and H. Fujikawa. 2019a. Comprehensive study of the boundaries of enterotoxin A production and growth of Staphylococcus 
aureus at various temperatures and salt concentrations. J. Food Sci. 84:121-126. https://doi.org/10.1111/1750-3841.14402.

Elahi, S., and H. Fujikawa. 2019b. Effects of lactic acid and salt on enterotoxin A production and growth of Staphylococcus aureus. J. Food Sci. 84:3233-3240. https://doi.org/10.1111/1750-3841.14829.

Erkmen, O. 1995. Behavior of Staphylococcus aureus in Turkish Feta cheese during manufacture and ripening. J. Food Prot. 58:12011205. https://doi.org/10.4315/0362-028X-58.11.1201.

Essid, I., and M. Hassouna. 2013. Effect of inoculation of selected Staphylococcus xylosus and Lactobacillus plantarum strains on biochemical, microbiological and textural characteristics of a Tunisian dry fermented sausage. Food Control 32:707-714. https://doi.org/ 10.1016/j.foodcont.2013.02.003.

Fox, P. F., T. P. Guinee, T. M. Cogan, and P. L. H. McSweeney. 2017. Fundamentals of Cheese Science. Springer, Boston, MA.

Gatadi, S., Y. V. Madhavi, S. Chopra, and S. Nanduri. 2019. Promising antibacterial agents against multidrug resistant Staphylococcus aureus. Bioorg. Chem. 92:103252. https://doi.org/10.1016/j .bioorg.2019.103252.

Ibrahim, G. F., A. Baldock, D. Radford, and L. Ireland. 1981. Inhibition of Staphylococcus aureus growth and enterotoxin-A production in Cheddar cheese produced with variable starter activity. J. Food Prot. 44:263-267. https://doi.org/10.4315/0362-028X-44 .4 .263 .

Le Loir, Y., F. Baron, and M. Gautier. 2003. Staphylococcus aureus and food poisoning. Genet. Mol. Res. 2:63-76.

Le Marc, Y., L. Valík, and A. Medved'ová. 2009. Modelling the effect of the starter culture on the growth of Staphylococcus aureus in milk. Int. J. Food Microbiol. 129:306-311. https://doi.org/10 $.1016 /$ j.ijfoodmicro.2008.12.015.

Madureira, A. R., M. E. Pintado, A. M. P. Gomes, and F. X. Malcata. 2011. Incorporation of probiotic bacteria in whey cheese: Decreasing the risk of microbial contamination. J. Food Prot. 74:11941199. https://doi.org/10.4315/0362-028X.JFP-10-217.

Medved’ová, A., L. Valík, Z. Sirotna, and D. Liptakova. 2009. Growth characterisation of Staphylococcus aureus in milk: A quantitative approach. Czech J. Food Sci. 27:433-453.

Mohammadi, K., and S. Hanifian. 2015. Growth and enterotoxin production of Staphylococcus aureus in Iranian ultra-filtered white cheese. Int. J. Dairy Technol. 68:111-117. https://doi.org/10 .1111/1471-0307.12158

Notermans, S., and C. Heuvelman. 1983. Combined effect of water activity, $\mathrm{pH}$ and sub-optimal temperature on growth and enterotoxin production of Staphylococcus aureus. J. Food Sci. 48:1832-1835. https://doi.org/10.1111/j.1365-2621.1983.tb05096.x.

Novick, R. P. 2003. Autoinduction and signal transduction in the regulation of staphylococcal virulence. Mol. Microbiol. 48:1429-1449. https://doi.org/10.1046/j.1365-2958.2003.03526.x.

Osaili, T. M., A. A. Al-Nabulsi, A. N. Olaimat, R. R. Shaker, M. Taha, and R. A. Holley. 2014. Survival of Escherichia coli O157:H7 during manufacture and storage of white brined cheese. J. Food Sci. 79:M1750-M1755. https://doi.org/10.1111/1750-3841.12547.

Osaili, T. M., A. A. Al-Nabulsi, M. H. Taha, M. A. Al-Holy, A. R. Alaboudi, W. M. Al-Rousan, and R. R. Shaker. 2012. Occurrence and antimicrobial susceptibility of Listeria monocytogenes isolated from brined white cheese in Jordan. J. Food Sci. 77:M528-M532. https://doi.org/10.1111/j.1750-3841.2012.02877.x.

Quijada, N. M., M. Hernández, E.-A. Oniciuc, J. M. Eiros, I. Fernández-Natal, M. Wagner, and D. Rodríguez-Lázaro. 2019. Oxacillinsusceptible mecA-positive Staphylococcus aureus associated with processed food in Europe. Food Microbiol. 82:107-110. https://doi .org/10.1016/j.fm.2019.01.021.

Singh, P., and A. Prakash. 2008. Isolation of Escherichia coli, Staphylococcus aureus and Listeria monocytogenes from milk products sold under market conditions at Agra region. Acta Agric. Slov. 92:83-88.

Stecchini, M. L., I. Sarais, and M. de Bertoldi. 1991. The influence of Lactobacillus plantarum culture inoculation on the fate of Staphylococcus aureus and Salmonella typhimurium in Montasio cheese. Int. J. Food Microbiol. 14:99-109. https://doi.org/10.1016/0168 -1605(91)90096-8.

Tatini, S. R. 1973. Influence of food environments on growth of Staphylococcus aureus and production of various enterotoxins. J. Milk Food Technol. 36:559-563. https://doi.org/10.4315/0022-2747-36 .11.559.

Turhan, M., and G. Kaletunç. 1992. Modeling of salt diffusion in white cheese during long-term brining. J. Food Sci. 57:1082-1085. https: //doi.org/10.1111/j.1365-2621.1992.tb11269.x.

Valero, A., F. Pérez-Rodríguez, E. Carrasco, J. M. Fuentes-Alventosa, R. M. García-Gimeno, and G. Zurera. 2009. Modelling the growth boundaries of Staphylococcus aureus: Effect of temperature, $\mathrm{pH}$ and water activity. Int. J. Food Microbiol. 133:186-194. https:// doi.org/10.1016/j.ijfoodmicro.2009.05.023.

Vernozy-Rozand, C., A. Meyrand, C. Mazuy, M.-L. Delignette-Muller, G. Jaubert, G. Perrin, C. Lapeyre, and Y. Richard. 1998. Behaviour and enterotoxin production by Staphylococcus aureus during the manufacture and ripening of raw goats' milk lactic cheeses. J. Dairy Res. 65:273-281. https://doi.org/10.1017/ S0022029997002781.

Viçosa, G. N., C. V. Botelho, C. Botta, M. Bertolino, A. F. de Carvalho, L. A. Nero, and L. Cocolin. 2019. Impact of co-cultivation with Enterococcus faecalis over growth, enterotoxin production and gene expression of Staphylococcus aureus in broth and fresh cheeses. Int. J. Food Microbiol. 308:108291. https://doi.org/10.1016/j .ijfoodmicro.2019.108291.

WHO (World Health Organization). 2017. Global priority list of antibiotic-resistant bacteria to guide research, discovery, and development of new antibiotics. Accessed May 8, 2020. https://www .who.int/medicines/publications/global-priority-list-antibiotic -resistant-bacteria/en/.

\section{ORCIDS}

Anas A. Al-Nabulsi $\odot$ https://orcid.org/0000-0002-9592-055X Roa A. AbuNaser (ㄴ) https://orcid.org/0000-0002-8520-7515 Mutamed Ayyash @ https://orcid.org/0000-0002-9312-500X Murad A. Al-Holy @ 1 https://orcid.org/0000-0001-8627-0391 Richard A. Holley @i https://orcid.org/0000-0001-7583-805X 